\title{
A new syndrome: Heart defects, laryngeal anomalies, preaxial polydactyly, and colonic aganglionosis in sibs
}

Taosheng Huang, $M D, P h D^{1}$, Ellen R. Elias, $M D^{2}$, John B. Mulliken, $M D^{3}$, Daniel J. Kirse, $M D^{4}$, and Lewis B. Holmes, $M D^{5}$

We present two siblings, one male and one female, who have heart defects, duplication of toes, airway anomalies, and aganglionosis. The brother also has a bilateral complete cleft lip and palate. His airway anomalies include short epiglottis and aryepiglottic folds, which are different from his sister who has a bifid epiglottis with a central epiglottic mass. Both siblings have had some developmental delay. This constellation of anomalies appears to be unique and may represent a new autosomal recessive disorder. Genetics in Medicine, 1999;1(3):104-108

\section{INTRODUCTION}

We describe two siblings, one male and one female, with multiple congenital anomalies, including Hirschsprung disease, heart defects, preaxial polydactyly and laryngeal anomalies. This phenotype is distinctive from other multiple congenital anomaly syndromes previously reported to be associated with colonic aganglionosis, and appears to be a "new" autosomal recessive disorder.

\section{CLINICAL REPORTS}

Case 1: JC was born by spontaneous vaginal delivery to a 33 year-old G4 P4 mother at 38 weeks of gestational age. There had been no known exposure to human teratogens during the pregnancy. The birth weight was $3.7 \mathrm{~kg}$ (75-95th percentile); length was $49 \mathrm{~cm}$ (25th percentile); and head circumference was 35.5 $\mathrm{cm}$ (50-75th percentile).' The anomalies noted at birth included bilateral complete cleft lip and palate, telecanthus with an inner canthal distance of $3.25 \mathrm{~cm}$ (95th percentile) (Fig. 1A), dupli-

\footnotetext{
From the 'Division of Genetics and Metabolism, Children's Hospital, and Department of Genetics, Howard Hughes Medical Institute, Harvard Medical School, Boston, MA; the 'Coordinated Care Service, Children's Hospital, Boston, MA; the ${ }^{3}$ Division of Plastic Surgery, Children's Hospital, Boston, MA; the 'Department of Otolaryngology, University of Kansas Medical Center, Kansas City, KS; and the ${ }^{5}$ Genetics and Teratology Unit, Pediutric Service, Massachusetts General Hospital, Harvard Medical School, Boston, MA.
}

Address correspondence to: Lewis B. Holmes, MD, Genctics and Teratology Unit, Warren 801, Pediatric Service, Massachusetts General Hospital, Harvard Medical School, Boston, MA 02114.

$\circlearrowleft 1999$ Genetics in Medicine. All rights reserved. cation of the great toes, and postaxial polydactyly of the right foot. Radiographs of the feet showed bilateral duplication of the hallux and the right fourth toe. (Fig. 1B).

An echocardiogram showed an atrial septal defect, coarctation of the aorta, a large patent ductus arteriosus, cleft mitral valve, and a mildly hypoplastic aortic arch with a gradient of $15-20 \mathrm{~cm} \mathrm{H} \mathrm{H}_{2} \mathrm{O}$ between the upper and lower extremities (normally, the pressures are almost equal). Cardiac catheterization confirmed the presence of these anomalies and also demonstrated anomalous venous return.

JC developed a distended abdomen at one day of age due to spontaneous perforation of the large bowel, and underwent a colostomy and appendectomy. Histologic studies showed aganglionosis of the entire colon and the appendix; cholinesterase staining was consistent with the diagnosis of Hirschsprung disease.

JC developed respiratory distress at two months of age. Direct laryngoscopy showed a short epiglottis and short aryepiglottic folds with redundant mucosa in the arytenoids (Fig. 1C). The true vocal cords, subglottics, and distal tracheobronchial tree were normal. His respiratory distress resolved after epiglottoplasty.

JC has shown mild developmental delay, particularly in expressive language usage. At age of 24 months, he can walk, run, feed himself with utensils, knows multiple body parts, and uses multiple signs to communicate. He only uses 2 words verbally. He has been receiving intensive early intervention service where formal evaluation at the age of 20 months revealed most skills in the 10-month range.

The karyotype in peripheral blood and skin fibroblast cells showed 46, XY; there was no deletion of chromosome 22q detected in a FISH analysis. The head ultrasonogram identified no abnormalities.

Case 2: AC (Fig. 2A), the older sister of JC, was born at 38 weeks gestational age after an uncomplicated pregnancy. Her birth weight was $4.4 \mathrm{~kg}$ (greater than 97th percentile, large for the gestation age). ${ }^{1}$ She also had duplication of the great toes (Fig. 2B). An echocardiogram and later cardiac catheterization demonstrated an atrial septal defect, cleft mitral valve, and anomalous venous return from the left superior vena cava to the coronary sinus.

$\mathrm{AC}$ had developmental delay, most obvious in language development. At 18 months of age, she used no words. Her receptive and expressive language was typical for a child of eight to nine 

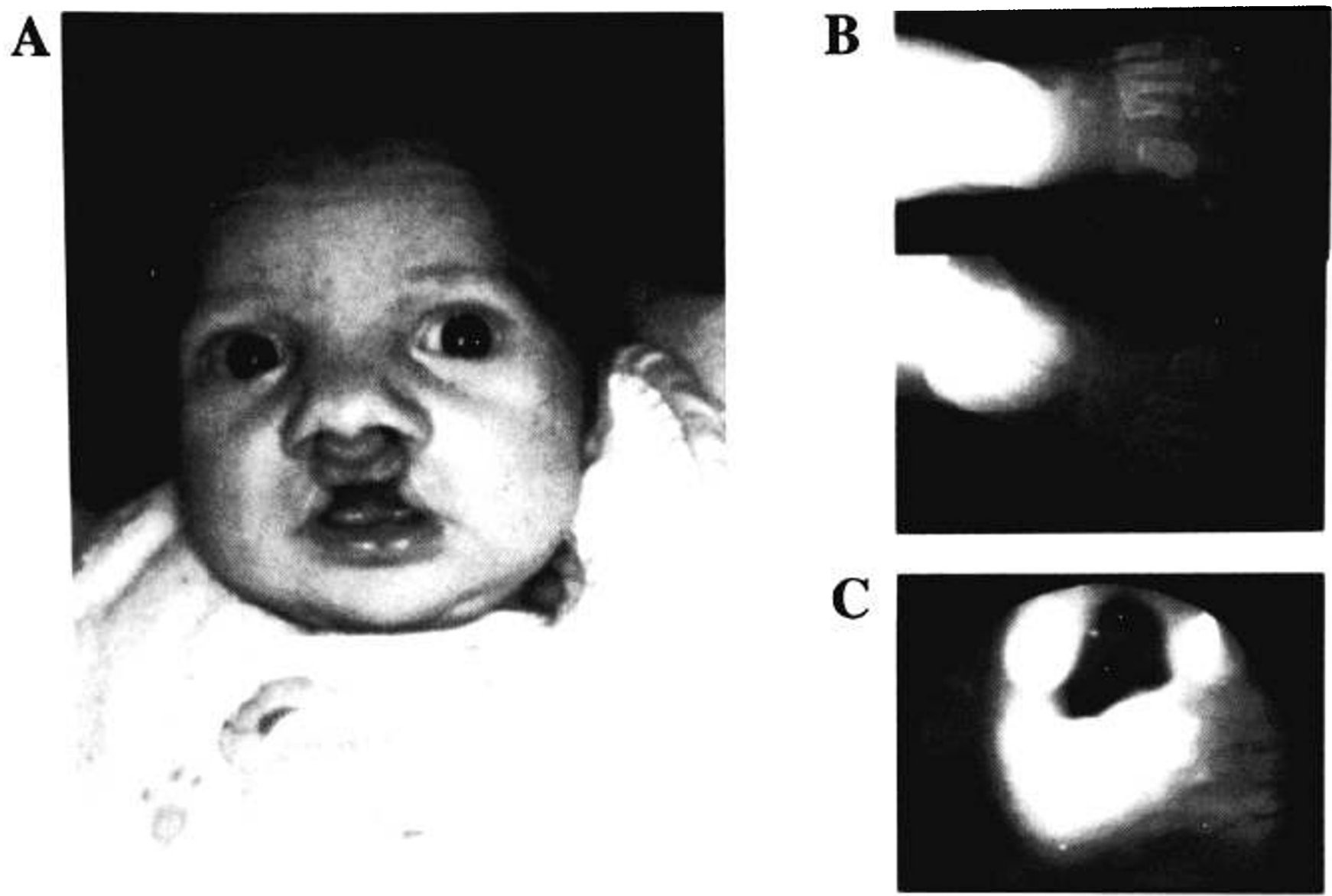

Fig. 1 (A) Case 1 at age of 2 1/2 months, showing bilateral cleft lips and cleft palates. $(B)$ A foot X-ray shows bilateral duplication of the halluces and duplication of the right fourth toe. (C) Direct laryngoscopy shows short epiglottis and short aryepiglottic fold.

months with skills scattered to the 12 month level. She also has had fine motor delay, possibly associated with decreased muscle tone in the hands. After intensive early intervention services, her motor development has improved significantly, but she continues to show overall delay with more significant weakness in language and speech production.

AC was evaluated for chronic constipation after her younger brother, JC, had been diagnosed with Hirschsprung disease. Histologic studies from a rectal biopsy also showed aganglionosis of the sigmoid colon.

AC also had history of stridor, particularly when she was sleeping. Direct laryngoscopy showed severe epiglottic abnormality including bifid epiglottis with a central epiglottic mass (Fig. 2C), but true vocal cords, subglottics, main stem and segmental bronchi, and trachea were normal.

\section{FAMILY HISTORY}

The parents are not related and are in a good health. In addition to JC and AC, they have a 4-year-old son and 3-year-old daughter. The 4-year-old son is healthy and has had normal development. However, the 3-year-old daughter also has a bifid uvula and developmental delay. The developmental pattern in the 3 younger siblings is similar, with language delay being most prominent. The 3-year-old daughter stood at 13 months, walked at 15 months, and ran at 18 months. She did not babble until 1 year of age and did not use her first word until 29 month of age. Evaluation at $21 / 2$ years of age showed that her receptive and expressive languages were at a 9- to 10-month level with skills scattered to the 12-month level on the Verbal Comprehension Scale of the Reynell Development Scale. On physical examination, she had macrocephaly and midfacial hypoplasia; her weight was $15.8 \mathrm{~kg}$ (50-75th percentile); her height was $98 \mathrm{~cm}$ (50th percentile); her head circumference was $52 \mathrm{~cm}$ (98th percentile); but her inner canthal distance was $2 \mathrm{~cm}$ (less than $2 \mathrm{nd}$ percentile) interpupillary distance was $4 \mathrm{~cm}$ (less than $2 \mathrm{nd}$ percentile), and outer canthal distance was $8 \mathrm{~cm}$ (75-97th percentile). ${ }^{1}$ Echocardiogram and a brain MRI identified no structural abnormalities. She has no other known anomalies. The ancestors of this family are from Ireland, England, Germany, and Mexico. There is no family history of chronic constipation. A maternal cousin had an atrial septal defect and ventricular septal defect. A paternal cousin had a ventricular septal defect. The family history was otherwise unremarkable. No other relatives are known to have dysmorphic features or congenital anomalies.

\section{DISCUSSION}

We report two siblings with a similar pattern of multiple malformations. Since JC and AC are male and female offspring of healthy patents, autosomal recessive inheritance seems most 

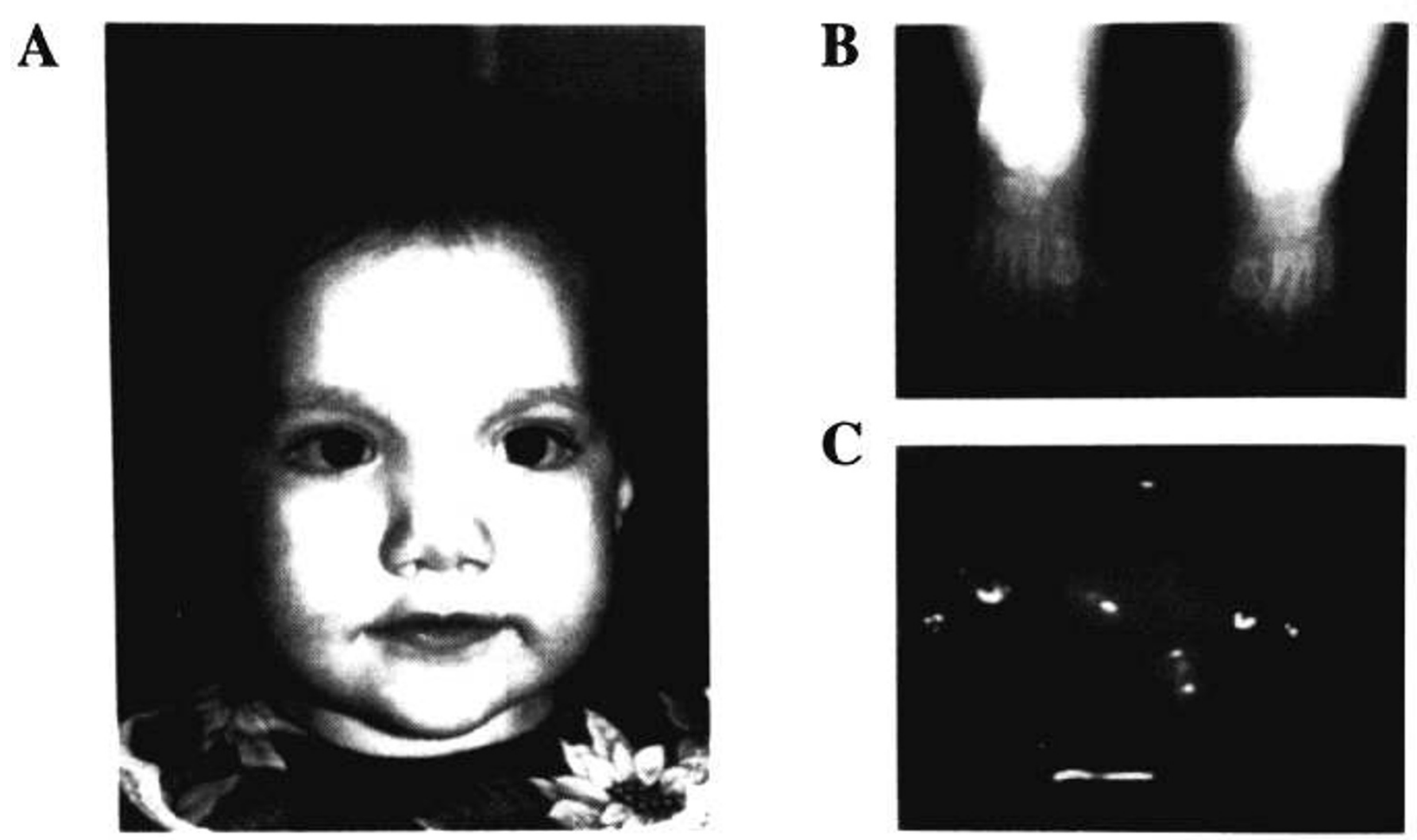

Fig. 2 (A) Case 2 at age of 2 1/2 years. (B) A foot X-ray shows bilateral duplication of the great toes, but the fourth right toe is normal. (C) Direct laryngoscopy shows a bifid epiglottis and an unusual central mass of the epiglottis between separated epiglottis.

Table 1

Associations of Hirschsprung disease with other congenital anomalies

\begin{tabular}{|c|c|c|c|c|c|c|c|c|}
\hline & IC & $\mathrm{AC}$ & Nowaczyk et al. & Lawrence et al. & McPheson et al. & Santos et al. & Pierpont et al. & Jespers et al. \\
\hline Hirschsprung & + & + & + & + & malrotation & + & + & + \\
\hline Cleft Palate & + & - & - & - & + & - & + & - \\
\hline Cleft Lip & + & - & - & - & + & - & + & - \\
\hline Cardiac defects & $\begin{array}{l}\text { ASD, VSD, } \\
\text { PDA cleft MV, } \\
\text { hypoplastic } \\
\text { aorta, AVR }\end{array}$ & ASD, VSD, AVR & ASD & VSD & $\begin{array}{l}\text { hypoplastic left } \\
\text { heart, DORV, PS }\end{array}$ & - & - & $\begin{array}{l}\text { ASD, } \\
\text { aneurysm, } \\
\text { PDA }\end{array}$ \\
\hline Limb anomalies & $\begin{array}{l}\text { duplication of } \\
\text { bilateral great } \\
\text { toes and right } \\
4 \text { th toe }\end{array}$ & $\begin{array}{l}\text { duplication of } \\
\text { bilateral } \\
\text { great toes }\end{array}$ & $\begin{array}{l}\text { postaxial } \\
\text { polydactyly } \\
\text { of hands }\end{array}$ & $\begin{array}{l}\text { postaxial } \\
\text { polydactyly } \\
\text { of hands }\end{array}$ & bifid thumb & $\begin{array}{l}\text { preaxial } \\
\text { polydactyly }\end{array}$ & - & - \\
\hline Tracheal anomalies & $\begin{array}{l}\text { short epiglottis, } \\
\text { short } \\
\text { aryepiglottic } \\
\text { fold }\end{array}$ & $\begin{array}{l}\text { bifid epiglottis } \\
\text { and an unusual } \\
\text { epiglottic mass }\end{array}$ & - & - & - & - & - & $\begin{array}{l}\text { Laryngeal } \\
\text { pharyngeal } \\
\text { hypoplasia }\end{array}$ \\
\hline MR or DD & + & + & & & & & + & + \\
\hline Hearing loss & - & - & & & & + & - & - \\
\hline Renal anomalies & - & - & & & & & & \\
\hline CNS anomalies & - & - & & & & + & & \\
\hline
\end{tabular}

ASD, atrial septal defect; VSD, ventricular septal defect; MV, mitral valve; AVR, anomalous venous return; MR, mental retardation; DD, developmental delay; CNS, central nervous system; DORV, double outlet of the right ventricle; PS, pulmonic stenosis; PDA, patent ductus arteriosus. 
likely. The clinical findings in these two patients are distinctive from those reported to date in association with Hirschsprung disease. A comparison of features in our patients and those reported with similar phenotypes is shown in Table $1 .^{3-9}$

Hirschsprung disease is genetically heterogeneous. At least three genes for Hirschsprung disease have been identified: the RET proto-oncogene, the endothelin receptor- $\mathrm{B}$ gene, and the endothelin-3 gene. ${ }^{10-12}$ The RET protein is a tyrosine kinase receptor. In Hirschsprung disease, the RET mutations lead to loss of function. Ten to forty percent of patients with familial Hirschsprung disease were found in one study to have an RET mutation. ${ }^{13}$

In analysis of a large kindred, a G-to-T transversion mutation in exon 4 of the endothelin-B receptor is associated with Hirschsprung disease. ${ }^{14}$ Twenty-one percent of the heterozygotes and $74 \%$ of homozygotes with the mutation in the endothelin-B receptor had aganglionosis of the intestine. A targeted interruption of the mouse endothelin-3, a ligand of the endothelin-B receptor, caused megacolon. ${ }^{15}$ This and other findings suggest that interaction of endothelin- 3 and its receptors is crucial for neural crest-derived cell lineages. ${ }^{16}$ Mice, in which the endothelin-B receptor gene had been deleted, showed a phenotype similar to that of our patients, i.e., intestinal aganglionosis, cardiac defects, and cleft lip/cleft palate. However, these genetically engineered mice do not have limb anomalies (Yanagisawa, personal communication).${ }^{15}$ In addition, mice with the deletion have a spotted white color.

Chakravarti ${ }^{17}$ estimated that the RET mutation accounts for $50 \%$ of familial Hirschsprung cases whereas the endothelin-B receptor mutation accounts for about $5 \%$. In his studies, the majority of patients with the endothelin-B receptor mutation have short segmental aganglionosis, compared with only $25 \%$ of RET-associated patients with short segment. In our patients, one has short segment and one has entire colon aganglionosis, supporting the previous finding that the short segment and long segment Hirschsprung disease can be caused by the same underlying genetic defect. ${ }^{18}$ However, these two anatomic variants of Hirschsprung disease still have different clinical significance because their management is different.

The case presented herein includes a constellation of malformations not previously described in the literature; however, the association of the bifid epiglottis with polydactyly has been reported. ${ }^{19,20}$ Although during embryonic development, early laryngeal development and limb formations occur at the same time, the mechanism of this association is unknown. In Pallister-Hall syndrome, malformation can be very extensive. In addition to polydactyly and bifid epiglottis, Hall et al. ${ }^{21}$ described six patients with this syndrome who also have hypothalamic hamartoblastoma, imperforate anus, abnormal lung lobulation, renal anomalies, nail hypoplasia, multiple buccal frenula, congenital heart disease, and hypothyroidism.

Recently, McClay et al..$^{19}$ reported a familial bifid epiglottis associated with polydactyly in three generations. One member of this family also had a congenital heart disease. Bifid epiglottis and polydactyly are variable. There is no consanguinity in this family, indicating an autosomal dominant inherited pattern.

Among the differential diagnosis is Oro-Facial-Digital syndrome, type II, which is characterized by cleft tongue, conductive hearing loss, and partial duplication of hallux. Steichen-Gersdorf et al..$^{22}$ reported a case with type II Oral-Facial-Digital syndrome. The features in their case included hypoplastic epiglottis and larynx, a stenosis of the trachea, pre-and postaxial polydactyly, growth retardation, and hearing loss. The absence of Hirschsprung disease and heart defects is distinct from our patients.

The developmental pattern in the 3 younger siblings is similar, with language delay being most prominent. Although the older sibling has no cardiac, limb, or intestinal anomalies, she may represent a very mild manifestations of the same disorder. Another explanation might be that the developmental delay is unrelated and represents a separate trait in this family. Molecular studies in the future may solve this puzzle.

In conclusion, we describe two siblings, one male and one female, with cardiac defects, laryngeal anomalies, preaxial polydactyly, and aganglionosis. The parents are normal and unrelated. This condition may be a new autosomal recessive syndrome. Molecular studies for mutation of RET and endothelin receptor $\mathrm{B}$ are in progress.

\section{Acknowledgments}

We are grateful to this magnificent family for their cooperation. T.H. is supported by NIH/NIGMS grant T32GM07748. These studies were also supported in part by the Peabody Foundation, Boston, MA. We are also in debt to Steve Depaloma, $\mathrm{PhD}$ for his critical reading for this manuscript.

\section{References}

1. Jones KL. Smith's recognizable patterns of human malformation, 5th edition. Philadelphia: WB Saunders Company, 1996.

2. Tan ST, Mulliken JB. Phertelorism. Nosologic analysis of 90 patients. Plast Reconstr Surg 1997;99:317-327.

3. Passarge E. Whither polygenic inheritance: Mapping Hirschsprung disease. Nat Genet 1993;4:325-326.

4. Nowaczyk MJM, James AG, Superina R, Siegel-Bartlet J. Hirschsprung disease, postaxial polydactyly, and atrial septal defect. Am J Med Genet 1997;68:74-75.

5. Laurence KM, Prosser R, Rocker I, Pearson JF, Richards C.: Hirschsprung disease associated with congenital heart malformation, broad big toe, and ulnar polydactyly in sibs: A case for fetoscopy. J Med Genet 1975;12:334-338.

6. McPherson E, Clemens M. Cleft lip and cleft palate, characteristic facial appearance, malrotation of the intestine, and lethal congenital heart dis ease in two sibs. Am J Med Genet 1996;62:58-60.

7. Santos H, Mateus J, Leal MJ. Hirschsprung disease associated polydactyly, unilateral renal agenesis, hypertelorism, and congenital deafness: A new autosomal recessive syndrome. J Med Genet 1988;25:204-208.

8. Pierpont JW, Jacques D, Seaver HL, Erikson RP. A family with unusual Waardenburg syndrome type I (WSI), cleft palate, and Hirschsprung disease is not linked to PAX3. Clin Genet 1995;47:139-143.

9. Jespers A, Buntinx I, Melis K, Vaerenberg M, Janssens G. Two siblings with midline field defects and Hirschsprung disease: Variable expression of Toriello-Carey or new syndrome? Am J Med Genet 1993;47:299-302.

10. Eng C. The RET proto-oncogene in multiple endocrine neoplasia type 2 and Hirschsprung's disease. N Engl J Med 1996;335:943-951.

11. Attie T, Amiel J, Jan D, Edery P, Pelet A, Salomon R, Munnich A, Lyonnet S, Nihoul-Fekete C. Genetics of Hirschsprung disease. Ann Chir 1996;50:538-541.

12. Auricchio A, Casari G, Staiano A, Ballabio A. Endothelin-B receptor mutation in patients from a non-inbred population. Hum Mol Genet 1996;5:351-354.

13. Pasini B, Borrello MG, Greco A, Bongarzone I, Luo Y, Mondellini P, Alberti L, Miranda C, Arighi E, Bocciardi R, et al. Loss of function effect of RET mutation causing Hirschsprung disease, Nat Genet 1995;10:35-40.

14. Puffenberger EG, Kompanek AJ, Kauffman ER, Mascari M, Ladda R, 
Chakravarti A. Pedigree analysis of a large Mennonite kindred segregating Hirschsprung disease (abstract). Am / Med Genet (suppl.) 1992;A4.

15. Hosoda K, Hammer R, Richardson IA, Baynash AG, Cheung IC, Giaid A, Yanagisawa $M$. Targeted and natural (Piebald-lethal) mutations of endothelin-B receptor gene produce megacolon associated with spotted coat color in mice. Cill 1994;79:1267-1276.

16. Baynash AG, Hosoda K, Giaid A, Richardson IA, Emoto N, Hammer RE, Yangisawa $M$. Interaction of endothelin- 3 with endothelin-B receptor is essential for development of epidermal melanocytes and enteric neuron. Coll 1994;79:1277-1285.

17. Charkravati A. Endothelin receptor-mediated signaling in Hirschsprung disease. Hum Mol Genct 1996;5:303-307.

18. Edery P, Pelet A, Mulligan LM, Abel L, Attie T, Dow E, Bonneau D, David A, Flintoff W, Jan D, et al. Long segment and short segment familial Hirschsprung disease: Variable clinical expression of the RET gene. I Med Genet 1994;31:602-606.

19. McClay JE, Wiatrak B, Proud VK. Bifid epiglottis and polydactyly: a new genetic syndrome. Otolaryngol Head Neck Surg 1987;1 16:129-133.

20. Goldenberg ID, Holinger LD, Bressler FJ, Hutchinson LR. Bifid epiglottis. Ann Otol Rhinol Laryngol 1996;105:155-157.

21. Hall JG, Pallister PD, Clarren SK, Beckwith JB, Wiglesworth FW, Fraser FC, Cho S, Benke PJ, Reed SD. Congenital hypothalamic hamartoblastoma, hypopituitarism, imperforate anus and postaxial polydactyly-a new syndrome? Part I: clinical, causal, and pathogenetic considerations. Am J Med Genet 1980;7:47-74.

22. Steichen-Gersdorf E, Gassner I, Covi B, Fischer H. Oral-facial-digital syndrome II. Transitional type between Mohr and Majewski syndrome: Report of a new case with congenital stenosis of the trachea. Clin Dysmorphol 1994;3:245-250. 